\title{
When distinction does not pay off - Investigating the determinants of European agritourism prices
}

Giampaolo Viglia, Portsmouth Business School, University of Portsmouth

Graziano Abrate, Universita del Piemonte Orientale

\begin{abstract}
Agritourism aims to deliver a particular kind of travel experience when compared to more mainstream types of hospitality, calling for the development of a specific model to design pricing strategies. This research examines the impact of three groups of factors on price: (i) internal attributes, classified as common or distinctive to other hospitality categories, (ii) external attributes, in terms of natural environment or cultural attractiveness and (iii) reputation, in the form of online and offline ratings. The proposed methodology, which provides a possible solution to collinearity amongst attributes, is the Shapley Value Regression. The database consists of 1268 agritourism establishments in five European countries. The findings show the relevance of the services that are common to mainstream types of hospitality and of the cultural attractiveness of the area. Managerial and policy implications build on the threat to the exclusivity of agritourism establishments with respect to traditional hotels in rural areas.
\end{abstract}

Keywords: Agritourism, Pricing strategies, eWOM, third-party ratings 
This research did not receive any specific grant from funding agencies in the public, commercial, or not-for-profit sectors.

\section{Introduction}

Agritourism brings visitors in a place where a private landowner offers recreational opportunities with an entrepreneurial purpose (Gao et al. 2013; Barbieri et al. 2015). The main factor for the success of this market is the guests' desire for relaxation, freedom, peace and the sense of authenticity. The activity is often complemented by accommodation services so that visitors can stay overnight and experience an area rich in natural resources and environmental quality (Sharpley \& Jepson 2011). Despite a general interest in this market, agritourism has increased only in the last decade, with a sustained revenue growth both in United States and in Europe (Khanal et al. 2014). Agritourism is not a new phenomenon. Since the early twentieth century, there is evidence that farmers have enriched recreational opportunities with tourism and hospitality accommodation services to diversify their entrepreneurial portfolio (Busby \& Rendle 2000). As highlighted by Vanslembrouck et al. (2005), building a solid reputation with guests is of paramount importance, as agritourism accommodations appear to have a more loyal customer base compared to hotels. Apart from locating the accommodation in a rural area rich in natural resources and environmental quality, agritourism entails organizing dedicated leisure activities (Barbieri \& Mshenga, 2008), investing substantially on farming to enrich the accommodation offer (Noev, 2013), and even designing personalized websites to advertise own products and farming experiences (AgriMarketing, 2016). Agritourism relates to ecotourism — in that it mainly involves travelling to relatively uncontaminated areas with the specific objective of admiring and enjoying the 
scenery, food and any existing cultural manifestations (Hultman et al., 2015;

Kazeminia et al., 2016). All this calls for a specific framework to understand if those distinctive aspects increase consumers' product valuations and favor pricing strategies that maximize sellers' profits (Kim et al. 2009).

The current study proposes a conceptual framework of the main determinants of the price charged for an over-night accommodation in an agritourism accommodation service by discussing the relevance of several groups of factors over the final price: (i) internal attributes, either common or distinctive to hotels, (ii) external attributes, either in terms of natural environment or cultural attractiveness and (iii) reputation, in the form of online and offline ratings.

To validate the proposed framework, the empirical part analyses data of more than 1200 agritourism accommodation services, distributed around the top five European countries in terms of rural accommodation (Noev 2013).

The methodology - based on the Shapley Value Regression (Shorrocks 2013) measures the relative contribution of each group of variables over the final price. In particular, the adopted approach goes beyond some intrinsic limitations of traditional hedonic pricing models, since it is robust to multicollinearity issues that usually arise when including reputation with other attributes of the product.

Based on a unique cross-national sample, the study has rich implications for the construct itself of agritourism and offers a new methodological contribution to the extant hedonic pricing literature on hospitality services (Espinet et al. 2003; Monty \& Skidmore 2003; Santana-Jiménez et al. 2015; Thrane 2007; Vanslembrouck et al. 2005; Zhang et al. 2011).

\section{Conceptual framework}


In scientific literature, the meaning of agritourism has been heterogeneous across geographical areas. In the US there is a lack of a legislative framework. Nonetheless, Gil-Arroyo, Barbieri and Rich $(2013,45)$ offer a tentative scholarly definition of agritourism as "a farm-related activity carried out on a working farm or other agricultural settings for entertainment or educational purposes." In Europe, the definition tends to be comparable, as there are policies governing agritourism incentives. As an activity that generally takes place in the countryside, agritourism falls under the umbrella of rural tourism. Nonetheless, while rural tourism also encompasses side activities that do not necessarily require over-night accommodation, such as river rafting or other adventure tourism activities (Santana-Jiménez et al. 2015), an agritourism establishment generally offers accommodation services (Busby \& Rendle 2000). For this reason, in Europe the term agritourism is frequently overlapped with rural accommodation (Noev 2013). Based on the heterogeneous definitions above, this article uses the term "agritourism" to refer to rural accommodation with different degrees of farming activity involved and specifically refers to the study of accommodation service in agritourism.

Despite the existence of a few empirical studies analyzing price determinants in agritourism, a systematic approach is still missing. Building on Elliot and Papadopoulos (2016), this study proposes a comphensive framework incorporating internal attributes, external attributes and reputation.

\subsection{Internal attributes}

Internal attributes are a solid baseline in determining the premium price applicable to tourism and hospitality services (White \& Mulligan 2002; Roubi \& Litteljohn 2004; Abrate \& Viglia, 2016). There is a lack of literature in regards to the relative 
contribution to the price of the services and the facilities common to hotels with respect to the ones that are distinctive to agritourism. In this second group there are the different farm-related activities, such as menus offering the farm's own products, the possibility for the guest to directly buy the seller's products, the presence of taste experiences as well as other recreational activities.

White and Mulligan (2002) were amongst the first authors to investigate the impact of internal attributes on the implicit prices of hotels with a hedonic pricing approach. In the subsequent years, other studies have found a strong price impact of several internal attributes: the number of rooms (Coenders et al. 2003; Roubi \& Litteljohn 2004), the room size (Monty \& Skidmore 2003) and the presence of beauty center or a swimming pool (Espinet et al. 2003; White \& Mulligan 2002). Vanslembrouck et al. (2005) transferred this approach to the agritourism market and showed, interestingly, that many of those attributes are still valid. Contrasting evidence concerns only the number of rooms available in the accommodation service, which presents a negative effect on the price level. The explanation of the authors for this finding is that, compared to the traditional hospitality industry, people visiting an agritourism venue are looking for a quiet and relatively small place that provides intimate interactions with nature. However, this negative relationship between number of rooms and prices is not supported by Ohe and Ciani (2011).

The picture becomes more puzzling when considering the attributes that are distinctive to the accommodation service in agritourism. Despite the specific product differentiation requires consistent investments (Sharpley, 2002), farming and educational activities present weak effects on prices (Fleischer \& Tchetchik 2005; Ohe \& Ciani 2011). 
In sum, the traditional attributes related to hotels show a more consistent effect on prices than the distinctive attributes of accommodation services in agritourism. Therefore, when assessing the impact of common versus distinctive attributes, the study portrays that:

H1: In accommodation services in agritourism the presence of internal distinctive attributes has a weaker effect on price levels compared to the internal attributes that are common to accommodation services in hotels.

\subsection{External attributes}

The environment that guests look for in agritourism is generally quite different compared to that found in traditional hotels. For the mainstream hospitality industry, some decisive variables are the number of competitors with available rooms and the proximity to central districts and to airports (Lee \& Jang 2011). In contrast, guests seeking-out an agritourism experience tend to prefer less crowded environments in areas with close relationships to nature and with easy access to cultural resources (Santana-Jiménez et al. 2015). The external environment combined with cultural landscape elements have been shown to be the main driver for the sense of spirituality that travelers are looking for while visiting these types of accommodation (Sharpley \& Jepson 2011).

While each country might have a different power in attracting tourists on the basis of many factors, such as a better climate (Zhang \& Jensen 2007) or a proper national brand (Fan 2006), the countryside, with its combination of undisturbed nature and culture, best exemplifies the intimate relationship between man and nature (Short 1981). This represents a fundamental requirement in successful accommodation services agritourism. 
On the one hand, the value of the geographical environment can be considered in its morphological elements (i.e., mountains, hills, plains, distance from seas and lakes). On the other hand, past literature has already operationalized the cultural environment as the sum multiple elements, World Heritage sites, protected designations of origin (PDO) and protected geographical indicators (PGI) for wines and foods (Ohe \& Ciani 2011). By dealing with the attractiveness of the area, Massidda and Etzo (2012) added also another variable, the number of incoming tourists into the region.

These contributions regarding external attributes suggest that price determinants include the geographical features of natural rural areas and several specific cultural attractions to be discovered in the area. In light of the previous rich evidence on the role of the different cultural elements, we portray that:

H2: When measuring the impact of external attributes on the price of accommodation services in agritourism, cultural elements explain a higher proportion of price compared to the natural geographic environment.

\subsection{Reputation}

Consumers often use numerical ratings to evaluate the reputation of tourism and hospitality services. Ratings tend to be quite influential in product choice because they provide a quick and easy way to assess and evaluate a product (Chen 2008; Tsang \& Prendergast 2009).

For hotels, the traditional form of measuring reputation is the star rating, which is a measure that remains important for overall evaluations (Zhang et al. 2011). However, the star-rating system suffers from several inconsistencies, due to different regulations 
in different regions (Núñez-Serrano et al. 2014). Inconsistencies across countries are even more dramatic in the case of agritourism because of the absence of official classification standards. To partially moderate this problem, a new third-party ranking system has been developed in recent years. This scale is the so-called ears-of-wheat scale (Stanciu et al. 2014) and consists of a standardized score given by experts to evaluate the listing.

A decade ago third-party judgments were considered to provide more accurate and complete evaluations compared to online consumer reviews (Herr et al. 1991; Bickart \& Schindler 2001). In contrast, nowadays eWOM is becoming a central cornerstone for measuring the reputation of the venue (Gretzel \& Yoo 2008; Chen 2008; Öğ̈̈ \& Taş 2012).

When evaluating online reviews, the two most effective cues considered by consumers are the review score (i.e., the average evaluation) and the review volume (i.e., the number of reviews of the establishment) (Zhang et al. 2010). In particular, the review score, according to Filieri (2015), is one of the most significant antecedents of trust among the several dimensions of online reviews. This piece of information is complemented by the number of online reviews, which presents a kind of visitor testimony that bears witness to positive or negative influence on a customers' perceived credibility (Fan et al. 2013) and on the level of awareness by the service being reviewed (Vermeulen \& Seegers 2009; Viglia et al. 2014).

The role of consumer-generated reviews is now considered trustworthy and independent (Mauri \& Minazzi 2013), despite online consumer review platforms being unable to actively prevent the owner of the hospitality destination (or competitors) from posting fraudulent reviews (Hu et al. 2012). In the agritourism setting, both standard classifications and online consumer reviews are in their infancy. 
To cope with this uncertainty, consumers might consult the two sources. Reputation is then assumed to be an additive process that accounts for both a more fluid dimension represented by online consumer reviews and the coexistence of the traditional thirdparty evaluation, which in the case of agritourism is represented by the ears-of-wheat scale.

In the hospitality industry, a number of hedonic pricing studies advocate for the use of the reputation factor as a predictor of room rates, as it is usually one of the variables with the highest explanatory power (see for example de Oliveira Santos 2016; Yim et al. 2014). Other studies avoid including any form of reputation amongst the predictors because the use of ratings raises concerns about misspecification and multicollinearity issues (Thrane 2005; Lee \& Jang 2011). In the context of this study, a plausible argument can be made to suggest that the internal or external attributes of agritourism accommodation services can have an influence on reputation through the ratings. Therefore, reputation can be seen as: (i) the dependent variable of a model where internal and external attributes are the predictors and (ii) one explanatory variable of a comprehensive model predicting prices. In other words, this study argues that consumers consider reputation as an additional attribute, which incorporates part of the value of the internal and external attributes but also comes with its own utility.

Based on the arguments presented above, the following testable hypotheses are proposed:

H3a: The groups of internal attributes, common to hotels and distinctive of agritourism accommodation services, positively affect the reputational level of the accommodation, both in its eWOM dimension and in its traditional third-party rating dimension. 
H3b: The groups of external attributes, cultural elements and natural geographical environment, positively affect the reputational level of the accommodation, both in its eWOM dimension and in its traditional third-party rating dimension.

H3c: Reputation incorporates both some of the value of the internal and external attributes and some additional specific effect on price.

Figure 1 presents the conceptual model. As agritourism accommodation services are a seasonal type of product (Embacher, 1994), the model considers the prices of both high and low season. In listings located close to mountains, high season prices are generally observed in winter. On the contrary, listings located close to sea present high season prices over summer periods.

The breakdown of the total price, based on the importance of the different groups of attributes, helps to understand which variables count more when defining the price level. The a priori expectation is that the hypotheses proposed in the conceptual model will hold both in the case of high and low season prices.

[Figure 1 here]

\section{Data and methodology}

The empirical analysis is based on five European countries: Austria, France, Germany, Italy and Spain. These five countries account for more than $60 \%$ of all the agritourism listings located in Europe (Noev 2013). 
Data integrate different sources of information. All the data from each specific listing (prices of high and low season, internal attributes and traditional reputation) were collected from the toprural.com website in March 2015. Toprural.com is the leader website for rural tourism in Europe, including more than 19000 listings. At the same time, natural and cultural attributes were retrieved from the database of origin and registration of the agricultural and rural development department of the European Commission (DORA, 2015). Finally, the number and value of online reviews of each available listing were retrieved from TripAdvisor in the same temporal period (March 2015).

The resulting dataset consists of 1268 agritourism listings, equally distributed among the five European countries considered.

Table 1 presents the list of analyzed variables, providing a classification in line with the proposed framework.

The price shown is per night and per person. Given the importance of seasonality in accommodation services, the study comprises both the high and low season prices. ${ }^{1}$ The price difference between low and high season, on average, is modest, suggesting that time-varying pricing strategies are more developed in the traditional hotel industry (Abrate \& Viglia, 2016).

The services offered are classified into two broad categories, distinguishing between services and facilities that are common to traditional hotels and the ones that are distinctive to agritourism. The rationale for categorizing common vs. distinctive attributes is their relation with rural activities (see Vanslembrouck et al., 2005).

\footnotetext{
${ }^{1}$ Austria and Germany represent a special case, in that just one undifferentiated price was available at the time of data collection.
} 
Around $40 \%$ of agritourism listings in the sample are located in mountain areas, $40 \%$ in the hills, and the remaining ones in lowland areas. Furthermore, around one third of the listings are positioned near to a lake or to the sea.

The sample comprises of 24 different regional districts (Andalucia, Aquitaine, BadenWürttemberg, Bayern, Castilla y León, Castilla-La Mancha, Cataluña, Illes Balears, Kärnten, Languedoc-Roussillon, Lombardia, Midi-Pyrénées, Niedersachsen, Provence-Alpes-Côte d'Azur, Rheinland-Pfalz, Rhône-Alpes, Salzburg, SchleswigHolstein, Steiermark, Tirol, Toscana, Trentino-Alto Adige, Umbria and Veneto).

[Table 1 here]

Following Ohe and Chiani (2011), the number of heritage sites certified by UNESCO and the number of products with protected origins (number of PDO and PGI) define the cultural attractiveness of the regional district. Two additional regional indexes account for the tourist demand (ITUR) and the competitive farm tourism pressure, measured by the density of agritourism establishments (IAGRI).

Moving to the reputational variables, the first problem is the absence of an official standard classification, even within the ears-of-wheat. In this latter classification, the maximum is three, four or five, depending on the country. Therefore, for the sake of homogeneity, all the scores were converted into a 1-5 scale with the following transformation for each rating $\left(\mathrm{x}_{i}\right)$ in the dataset: $\left(\mathrm{V}_{\max }-\mathrm{V}_{\min }\right) *\left(\mathrm{x}_{i}-\mathrm{V}_{\min }\right) /\left(\mathrm{v}_{\max }-\mathrm{V}_{\min }\right)+$ $\mathrm{V}_{\text {min }}$, where $\mathrm{V}_{i}$ are the values in the transformation scale (1-5), $\mathrm{x}_{i}$ is the empirical value to be transformed, and $\mathrm{v}_{i}$ are the values in the original scale (1-3 or 1-4). This method, adapted from IBM (2010), allows for the different ears-of-wheat classification ranges to be standardized. As for the online reputation, although there are multiple platforms 
where users can provide feedback, for the sake of comparability the study considers a unique source, TripAdvisor, by collecting the number of reviews and the average review score for each establishment.

In the conceptual model depicted in Figure 1, the price depends on several groups of attributes, as in the classical hedonic approach (Rosen 1974). The objective of this study is to understand the relative importance of factors (e.g., internal attributes, common vs. distinctive, etc.), rather than estimating specific coefficients. The Shapley Value Regression (SVR) provides a suitable methodological solution, since it allows estimating the contribution of each variable, or groups of variables, to a statistical indicator of goodness-of-fit of the underlying model, such as the R-squared (Huettner \& Sunder 2012; Shorrocks 2013). The SVR represents a statistical application of Shapley (1953), who originally developed the idea in the context of the cooperative game theory, whilst facing the problem of distributing to individuals the total outcome obtained by a coalition of players.

SVR takes into account all possible permutations of predictors and calculates the improvement in goodness-of-fit due to each predictor, by averaging over all possible combinations. This methodology is well suited for estimating the contribution of predictors against a response variable and it is specifically suitable when handling multicollinear data (Lipovetsky \& Conklin 2001). In fact, while multicollinearity raises doubts on the reliability of coefficients' estimates, which becomes very sensitive to the model specification, it has little effect on the overall fit of the equation (Studenmund 2010).

Formally, given a full regression model with $K$ explanatory variables, or groups of variables, $\left(x_{1}, x_{2}, \ldots, x_{K}\right)$, computing the contribution of each variable requires the estimation of all possible sub-models (considering all $K$ ! permutations of regressors): 


$$
R_{j}^{2}=\frac{1}{K !} \sum_{\theta} R^{2}\left(f\left(x_{j}^{\theta}, x_{j}\right)\right)-R^{2}\left(f\left(x_{j}^{\theta}\right)\right)
$$

where $j$ defines any of the $K$ ! variable orderings.

Thus, the Shapley value is the variable's average marginal contribution to R-squared over all possible orderings.

The application of SVR to the conceptual model entails the estimation of three empirical models. The first model accounts only for the direct impact of internal and external attributes on price ( $\mathrm{H} 1$ and $\mathrm{H} 2)$, ignoring the role of reputation (Model 1). Model 2 focuses on the impact of internal and external attributes on reputation (H3a and $\mathrm{H} 3 \mathrm{~b}$ ). Finally, Model 3 recognizes the role of reputation in affecting price levels per se as an additional component to internal and external attributes ( $\mathrm{H} 3 \mathrm{c})$.

Model 1: P = f(IC, ID, EN, EC, EF)

Model 2: $\mathrm{R}=\mathrm{f}(\mathrm{IC}, \mathrm{ID}, \mathrm{EN}, \mathrm{EC}, \mathrm{EF})$

Model 3: P = f(IC, ID, EN, EC, EF, R)

where, consistently with Table 1, the variables are grouped as follows:

$\mathrm{IC}=\{$ REST, POOL, MEET, DISAB, PETS, KIDS, BIKES, TV, WIFI, AIR, PARK $\}$

$\mathrm{ID}=\{$ MENU, SELL, TAST, TRIP, EDU, CLASS, WORK, RIDE, FARM $\}$

$\mathrm{EN}=\{$ MOUNT, HILL, PLAIN, LAKE, SEA $\}$

$\mathrm{EC}=\{$ PDIKM, HERIKM, IAGRI, ITUR $\} ;$

$\mathrm{R}=\{\mathrm{RATE}, \mathrm{NREV}, \mathrm{VREV}\}$.

In all the models, country fixed effects (EF) are included as an external factor to control for unobserved heterogeneity at the national level. 


\section{Results and discussion}

Table 2 presents the empirical evidence from Model 1. The estimation reaches a fairly good fit, in line with other hedonic price applications concerning agritourism (Vanslembrouck et al. 2005, Hernandez et al. 2016), and the model performs better in high season than in low season $(\mathrm{R}$-squared $=0.387 \mathrm{vs.} 0.283)$. The table summarizes the relative estimated Shapley values of the attributes, showing that, in high season, internal and external attributes are equally important in determining price levels, while in low season external attributes partially lose their explanatory power. ${ }^{2}$ One possible explanation for this finding is that in high season accommodation services better exploit the externalities coming from the surrounding areas. However, consistent patterns emerge within these two broad categories. Among internal attributes, common services to hotels are much more important than distinctive agritourism features, $42.3 \%$ vs. $7.7 \%$ in high season and $54.0 \%$ vs. $8.1 \%$ in low season. As per the external attributes, apart from unobserved country specific factors, the cultural richness determines the attractiveness of the geographical area more than the natural factor (respectively, $22.2 \%$ vs. $8.7 \%$ and $16.7 \%$ vs. $4.9 \%$ ).

[Table 2 here]

A sensitivity analysis tests the robustness of the results across sub-samples (Table 3a and $3 \mathrm{~b}$ ). Despite some heterogeneity between agritourism establishments located in mountains and plains, in both cases common attributes are the most important driver of clients' willingness to pay, while distinctive features play a limited role. Cultural

\footnotetext{
${ }^{2}$ Consistently with the scope of the paper, Table 2 to 5 present only the relative Shapley contribution of each group of explanatory variables to the R-squared of the estimated models. The full list of estimated coefficients is available upon request.
} 
attractiveness is particularly relevant in lowland areas, while the weight of internal attributes tends to increase in mountainous agritourism. The prominent role of common vs. distinctive internal attributes and cultural vs. natural factors holds across all analyzed countries, with a relative higher importance for the distinctive features in Italy and Germany.

In sum, these results give full support to $\mathrm{H} 1$ and $\mathrm{H} 2$.

[Table 3a here]

[Table $3 b$ here]

The second step of the empirical analysis aims to estimate the relative importance of attributes in explaining reputation ( $\mathrm{H} 3 \mathrm{a}$ and $\mathrm{H} 3 \mathrm{~b})$. Reputation is a multi-dimensional factor and can be measured either through traditional third-part classification systems or through the values and number of online reviews (eWOM). Thus, the study presents a principal component analysis where the inputs are the different sources of reputation (RATE, NREV, VREV) combined in a unique reputation index (PCAREP). The factorial analysis supports the choice of a unique component as this solution explains alone $70 \%$ of the total variance. The unique factor solution is supported also by the parallel analysis, which is the most reliable measure in defining the cut-off (Keeling 2000). This allows using this reputation index as the dependent variable of SVR in Model 2.

Table 4 supports $\mathrm{H} 3 \mathrm{a}$ and $\mathrm{H} 3 \mathrm{~b}$ in that it suggests that both internal and external attributes influence reputation. Among the external attributes, reputation is highly affected by the cultural attractiveness of the area and country specific aspects, while the natural environment has only a marginal impact. With regards to what impacts 
internal facilities and services, common attributes remain more important than distinctive ones ( $28 \%$ vs. $12 \%)$.

Overall, the results in Table 4 largely overlap the indications obtained in terms of price determinants (Table 2$)$, with quite a similar overall fit $(\mathrm{R}$-squared $=0.382)$. While the relative importance of the outlined factors is quite similar, whether explaining reputation or price, surprisingly the external attributes affect reputation even more than internal ones ( $60 \%$ vs. $40 \%$ ), suggesting that the relation between attributes and reputation goes beyond a relation with internal attributes (Yacouel and Fleischer 2012).

[Table 4 here]

The last step of the analysis focuses on the way reputation itself impacts on price. Model 3, which includes reputation in addition to internal and external attributes, improves the R-squared with respect to Model 1 and redefines the relative weights (Table 5 vs. Table 2).

[Table 5 here]

Specifically, while the increase in R-squared seems limited in both seasons, due to correlation between the reputation factor and the other attributes, the weight of reputation according to SVR is relevant both in high and low season (respectively, $20.4 \%$ and $25,3 \%$ ). This implies that the impact of reputation on price is twofold, giving support to $\mathrm{H} 3 \mathrm{c}$. First, in the case of high season, the inclusion of reputation improves the explanatory power of the model by $8.3 \%$, that is $(0.422-0.387) / 0.422$, 
suggesting that reputation has an impact after controlling for internal and external attributes. This improvement is even higher in the case of low season $(+12.9 \%)$. Nonetheless, reputation is not necessarily the last factor taken into account in the consumer decision-making process. The SVR, by averaging over all possible ordering of factors, replicates the existence of different consumer priorities with respect to the attributes that define their willingness to pay. This enables an estimation of the proper weight of reputation (more than 20\%). The residual, $12.1 \%$ in high season $(20.4-8.3)$ and $12.4 \%$ in low season $(25.3-12.9)$, suggests how reputation incorporates an evaluation of the other attributes. Accordingly, the pure effect of internal and external, once controlling for reputation, shrinks to approximately $40 \%$ each, while the relative importance within each category, as expected, remains consistent with the previous estimates, providing further support to $\mathrm{H} 1$ and $\mathrm{H} 2$.

\section{Conclusion}

Previous work has overlooked the impact on price of the peculiarities of agritourism compared with traditional hotels. To better understand what shapes price formulation, this study builds a conceptual framework and empirically validates it through the Shapley Value Regression. This method provides a possible solution to the problem of collinearity amongst attributes usually included in hedonic pricing models (Alegre et al. 2013).

The environmental-cultural attributes and the services that agritourism accomodations share in common with hotels have an importance over the final price that exceeds $70 \%$. These results cast doubt on the exclusivity of agritourism with respect to traditional hotels, as the presence of distinctive elements of an agritourism has a limited effect both on prices and reputation. Interestingly, while it is acknowledged 
some variability in the specific weights of the attributes, the results are consistent across the investigation for each of the European countries and between high and low season. This poses threats on the peculiarity of agritourism at macro level.

Local authorities and stakeholders should manage these apparently paradoxical preferences. The advertising campaigns for agritourism can highlight both the major cultural attractions of the land where the establishment is located and the specific hospitality services that agritourism can offer, in line with the traditional hospitality industry.

From a theoretical standpoint, the paper responds to the call for models to maximize marketing strategies in agritourism $(\mathrm{Wu}, 2016)$. Also, stemming from Elliot and Papadopoulos (2016), this study offers a "price-tag" to products in tourism destinations, i.e. accommodation services in agritourism. In line with the findings from Fleischer and Tchetchik (2005), the study supports the weak role of some specific internal distinctive attributes proper of agritourism accommodation services, such as farming and educational activities. Finally, the study expands the knowledge on the relevance of reputational elements, both in its online and offline dimension. In terms of practical implications, the findings suggest that operators should locate agritourism establishments in a geographical area rich in cultural attractions. In this sense, the planning phase assumes a critical relevance. Once the location is fixed, the premium price that comes from enriching the agritourism establishment with distinctive attributes is limited. Based on the high importance of the attributes that are common to the hotel industry, the research suggests a new operationalization of the agritourism construct as a hotel in a remote area. Specifically, following recent evidence on pay premium for ecotourism (Hultman et al., 2015; Kazeminia et al., 
2016), this study shows that what counts is the rural identity of the area rather than the rural identity of the agritourism establishment.

Although the results are quite consistent across countries, the peculiarities of both lowland areas, where the importance of cultural attractiveness stands out even more, and mountainous areas, where internal attributes of the establishments are even more salient, suggest the need to examine some areas specifically. Fulfilling this purpose, Hernández et al. (2016) recently investigated in depth the coexistence of rural and mass tourism within the specific Catalunya market.

A potential limitation is that some relevant attractions of agritourism, such as quality of the events and heritage attractions, cannot be easily converted into quantitative variables. This might partially untangle the portion of variance not explained in the models and advocate qualitative research approaches to complement these findings by further exploring consumer decision-making processes. In addition, this research focuses on the impact of agritourism on prices. However, as discussed in Tew and Barbieri (2012), this business serves also to educate the public about agriculture and to enhance the quality of life for the farm family, going beyond the economic benefits.

Future research can assess the effect of quality attributes on other profitability variables, considering as output variable the actual revenues generated by accommodation services in agritourism. Another direction for future research is an indepth analysis of consumers' motives towards choosing agritourism over traditional accommodation services. Sharpley and Jepson (2011) provide initial qualitative evidence. Segmenting customers through quantitative analyses will provide decisionmakers insights on the experiences these travellers are looking for. 
Finally, though the paper analyzes both high and low season prices, more

sophisticated time-varying price differentiations are now emerging also in agritourism accommodation services. In this sense, future research might investigate the impact of new dynamic pricing strategies in a sector that seems more reluctant towards pricing innovation with respect to hotels.

\section{References}

Abrate, G., \& Viglia, G. (2016). Strategic and tactical price decisions in hotel revenue management. Tourism Management, 55, 123-132.

AgriMarketing, E. (2016). Farm web site design specialists, Eckert AgriMarketing knows the Agritourism and direct farm market business. Retrieved June 26, 2016, from http://www.eckertagrimarketing.com/eckert-agritourism-website-design.php

Alegre, J., Cladera, M., \& Sard, M. (2013). Tourist areas: Examining the effects of location attributes on tour-operator package holiday prices. Tourism Management, 38, 131-141. doi:10.1016/j.tourman.2013.02.011

Barbieri, C., \& Mshenga, P. M. (2008). The role of the firm and owner characteristics on the performance of agritourism farms. Sociologia ruralis,48(2), 166-183.

Barbieri, C., Xu, S., Gil-Arroyo, C., \& Rich, S. R. (2015). Agritourism, farm visit, or . . . ? A Branding assessment for recreation on farms. Journal of Travel Research. doi:10.1177/0047287515605930

Bickart, B., \& Schindler, R. M. (2001). Internet forums as influential sources of consumer information. Journal of Interactive Marketing, 15(3), 31-40. doi:10.1002/dir.1014 
Busby, G., \& Rendle, S. (2000). The transition from tourism on farms to farm tourism. Tourism Management, 21(6), 635-642. doi:10.1016/s02615177(00)00011-X

Chen, Y. F. (2008). Herd behavior in purchasing books online. Computers in Human Behavior, 24(5), 1977-1992. doi:10.1016/j.chb.2007.08.004

Coenders, G., Espinet, J. M., \& Saez, M. (2003). Predicting random level and seasonality of hotel prices: a latent growth curve approach. Tourism Analysis, 8(1), 15-31. doi:10.3727/108354203108750148

de Oliveira Santos, G. E. (2016). Worldwide hedonic prices of subjective characteristics of hostels. Tourism Management, 52, 451-454. doi:10.1016/j.tourman.2015.07.001

DORA (2015) Database of origin and registration - Agriculture And Rural Development - European Commission. https:/lec.europa.eu/agriculturelquality_en. Accessed. 24 Mar. 2015.

Embacher, H. (1994). Marketing for Agri - tourism in Austria: Strategy and realisation in a highly developed tourist destination. Journal of Sustainable Tourism, 2(1-2), 61-76.

Elliot, S., \& Papadopoulos, N. (2016). Of products and tourism destinations: An integrative, cross-national study of place image. Journal of Business Research,69(3), 1157-1165. doi:10.1016/j.jbusres.2015.08.031

Espinet, J. M., Saez, M., Coenders, G., \& Fluvià, M. (2003). Effect on prices of the attributes of holiday hotels: A hedonic prices approach. Tourism Economics, 9(2), 165-177. doi:10.5367/000000003101298330

Fan, Y. (2006). Branding the nation: What is being branded? Journal of Vacation Marketing, 12(1), 5-14. doi:10.1177/1356766706056633 
Fan, Y.-W., Miao, Y.-F., Fang, Y.-H., \& Lin, R.-Y. (2013). Establishing the adoption of electronic word-of-mouth through consumers' perceived credibility. International Business Research, 6(3), . doi:10.5539/ibr.v6n3p58

Filieri, R. (2015). What makes online reviews helpful? A diagnosticity-adoption framework to explain informational and normative influences in e-WOM. Journal of Business Research, 68(6), 1261-1270

Fleischer, A., \& Tchetchik, A. (2005). Does rural tourism benefit from agriculture? Tourism Management, 26(4), 493-501. doi:10.1016/j.tourman.2003.10.003

Gao, J., Barbieri, C., \& Valdivia, C. (2013). Agricultural landscape preferences: Implications for Agritourism development. Journal of Travel Research, 53(3), 366-379. doi:10.1177/0047287513496471

Gil-Arroyo, C., Barbieri, C., \& Rozier Rich, S. (2013). Defining agritourism: A comparative study of stakeholders' perceptions in Missouri and north Carolina. Tourism Management, 37, 39-47. doi:10.1016/j.tourman.2012.12.007

Gretzel, U., \& Yoo, K. H. (2008). Use and impact of online travel reviews. In O’Connor, P., Hopken, W., Gretzel, U. (eds.), Information and Communication Technologies in Tourism, 35-46, Springer, Wien/New York.

Hernández, J. M., Suárez-Vega, R., \& Santana-Jiménez, Y. (2016). The interrelationship between rural and mass tourism: The case of Catalonia, Spain . Tourism Management, 54, 43-57. doi:10.1016/j.tourman.2015.10.015

Herr, P. M., Kardes, F. R., \& Kim, J. (1991). Effects of word-of-mouth and productattribute information on persuasion: An Accessibility-Diagnosticity perspective. Journal of Consumer Research, 17(4), 454. doi:10.1086/208570

Hu, N., P. A. Pavlou, \& Zhang, J. (2009). Overcoming the J-shaped distribution of product reviews. Communications of the ACM, 52(10), 144-147. 
Huettner, F., \& Sunder, M. (2012). Axiomatic arguments for decomposing goodness of fit according to Shapley and Owen values. Electronic Journal of Statistics, 6, 1239-1250. doi:10.1214/12-ejs710

Hultman, M., Kazeminia, A., \& Ghasemi, V. (2015). Intention to visit and willingness to pay premium for ecotourism: The impact of attitude, materialism, and motivation. Journal of Business Research, 68(9), 1854-1861. doi:10.1016/j.jbusres.2015.01.013

IBM (2010). Transforming different Likert scales to a common scale. Available at: http://www-01.ibm.com/support/docview.wss?uid=swg21482329 (accessed: 30 July 2015).

Kazeminia, A., Hultman, M., \& Mostaghel, R. (2016). Why pay more for sustainable services? The case of ecotourism. Journal of Business Research, 69(11), 49924997. doi:10.1016/j.jbusres.2016.04.069

Keeling, K. B. (2000). A regression equation for determining the Dimensionality of data. Multivariate Behavioral Research, 35(4), 457-468. doi:10.1207/s15327906mbr3504_02

Khanal, A. R., \& Mishra, A. K. (2014). Agritourism and off-farm work: Survival strategies for small farms. Agricultural Economics, 45(S1), 65-76. doi:10.1111/agec.12130

Kim, J.-Y., Natter, M., \& Spann, M. (2009). Pay what you want: A new participative pricing mechanism. Journal of Marketing, 73(1), 44-58. doi:10.1509/jmkg.73.1.44

Lee, S. K., \& Jang, S. (2010). Room rates of U.S. Airport hotels: Examining the dual effects of Proximities. Journal of Travel Research, 50(2), 186-197. doi:10.1177/0047287510362778 
Lipovetsky, S., \& Conklin, M. (2001). Analysis of regression in game theory approach. Applied Stochastic Models in Business and Industry, 17(4), 319-330. doi:10.1002/asmb.446

Massidda, C., \& Etzo, I. (2012). The determinants of Italian domestic tourism: A panel data analysis. Tourism Management, 33(3), 603-610. doi:10.1016/j.tourman.2011.06.017

Mauri, A. G., \& Minazzi, R. (2013). Web reviews influence on expectations and purchasing intentions of hotel potential customers. International Journal of Hospitality Management, 34, 99-107. doi:10.1016/j.ijhm.2013.02.012

Monty, B., \& Skidmore, M. (2003). Hedonic pricing and willingness to pay for bed and breakfast amenities in southeast Wisconsin. Journal of Travel Research, 42(2), 195-199. doi:10.1177/0047287503257500

Noev, N. (2013). Rural Tourism, Communities and EAFRD Funding 2014 - 2020. European Commission. Retrieved from http://www.seprat.net/files/Tiedostot/NN_Kotka_2013_Rural_Tourism_and_Com munities.pdf (accessed April 12, 2015).

Núñez-Serrano, J. A., Turrión, J., \& Velázquez, F. J. (2014). Are stars a good indicator of hotel quality? Assymetric information and regulatory heterogeneity in Spain. Tourism Management, 42, 77-87. doi:10.1016/j.tourman.2013.10.004

Öğüt, H., \& Onur Taş, B. K. (2012). The influence of internet customer reviews on the online sales and prices in hotel industry. The Service Industries Journal, 32(2), 197-214. doi:10.1080/02642069.2010.529436

Ohe, Y., \& Ciani, A. (2011). Evaluation of agritourism activity in Italy: Facility based or local culture based? Tourism Economics, 17(3), 581-601. doi:10.5367/te.2011.0048 
Rosen, S. (1974). Hedonic prices and implicit markets: Product differentiation in pure competition. Journal of Political Economy, 82(1), 34. doi:10.1086/260169

Roubi, S., \& Litteljohn, D. (2004). What makes hotel values in the UK? A hedonic valuation model. International Journal of Contemporary Hospitality Management, 16(3), 175-181. doi:10.1108/09596110410531168

Santana-Jimenez, Y., Sun, Y., Hernandez, J. M., \& Suarez-Vega, R. (2015). The influence of remoteness and isolation in the rural accommodation rental price among eastern and western destinations. Journal of Travel Research, 54(3), 380395. doi:10.1177/0047287513517423

Santana-Jiménez, Y., Suárez-Vega, R., \& Hernández, J. M. (2011). Spatial and environmental characteristics of rural tourism lodging units. Anatolia, 22(1), 89101. doi:10.1080/13032917.2011.556223

Shapley, L.S. (1953). A Value for n-person Games. In Contributions to the Theory of Games. Princeton University Press.

Sharpley, R. (2002). Rural tourism and the challenge of tourism diversification: The case of Cyprus. Tourism Management, 23(3), 233-244. doi:10.1016/s02615177(01)00078-4

Sharpley, R., \& Jepson, D. (2011). Rural tourism. Annals of Tourism Research, 38(1), 52-71. doi:10.1016/j.annals.2010.05.002

Shorrocks, A. F. (2012). Decomposition procedures for distributional analysis: A unified framework based on the Shapley value. The Journal of Economic Inequality, 11(1), 99-126. doi:10.1007/s10888-011-9214-z

Short, J. R. (1991). Imagined country: Society, culture and environment. Routledge. Stanciu, M., Dumitru, M., \& Tanase, M. (2014). Structure and development of the rural tourism network "Bienvenue a la ferme". Structure, 14(1), 357-361. 
Studenmund, A. H. (2010). Using econometrics: A practical guide (6th ed.). United States: Pearson Addison/Wesley.

Tew, C., \& Barbieri, C. (2012). The perceived benefits of agritourism: The provider's perspective. Tourism Management, 33(1), 215-224.

Thrane, C. (2005). Hedonic price models and sun-and-beach package tours: The Norwegian case. Journal of Travel Research, 43(3), 302-308. doi:10.1177/0047287504272034

Thrane, C. (2007). Examining the determinants of room rates for hotels in capital cities: The Oslo experience. Journal of Revenue \& Pricing Management, 5(4), $315-323$.

Tsang, A. S. L., \& Prendergast, G. (2009). Is a "star" worth a thousand words? European Journal of Marketing, 43(11/12), 1269-1280. doi:10.1108/03090560910989876

Vanslembrouck, I., Huylenbroeck, G., \& Meensel, J. (2005). Impact of agriculture on rural tourism: A Hedonic pricing approach. Journal of Agricultural Economics, 56(1), 17-30. doi:10.1111/j.1477-9552.2005.tb00120.x

Vermeulen, I. E., \& Seegers, D. (2009). Tried and tested: The impact of online hotel reviews on consumer consideration. Tourism Management, 30(1), 123-127. doi:10.1016/j.tourman.2008.04.008

Viglia, G., Furlan, R., \& Ladrón-de-Guevara, A. (2014). Please, talk about it! When hotel popularity boosts preferences. International Journal of Hospitality Management, 42, 155-164. doi:10.1016/j.ijhm.2014.07.001

White, P. J., \& Mulligan, G. F. (2002). Hedonic estimates of lodging rates in the Four corners region. The Professional Geographer, 54(4), 533-543. doi:10.1111/00330124.00348 
Wu, C. W. (2016). The international marketing strategy modeling of leisure farm. Journal of Business Research, 69(4), 1345-1350. doi:10.1016/j.jbusres.2015.10.105

Yacouel, N., \& Fleischer, A. (2011). The role of Cybermediaries in reputation building and price premiums in the online hotel market. Journal of Travel Research, 51(2), 219-226. doi:10.1177/0047287511400611

Yim, E. S., Lee, S., \& Kim, W. G. (2014). Determinants of a restaurant average meal price: An application of the hedonic pricing model. International Journal of Hospitality Management, 39, 11-20. doi:10.1016/j.ijhm.2014.01.010

Yule, G. U. (1912). On the methods of measuring association between Two attributes. Journal of the Royal Statistical Society, 75(6), 579. doi:10.2307/2340126

Zhang, J., \& Jensen, C. (2007). Comparative advantage. Annals of Tourism Research, 34(1), 223-243. doi:10.1016/j.annals.2006.08.004

Zhang, Z., Ye, Q., \& Law, R. (2011). Determinants of hotel room price. International Journal of Contemporary Hospitality Management, 23(7), 972-981. doi:10.1108/09596111111167551

Zhang, Z., Ye, Q., Law, R., \& Li, Y. (2010). The impact of e-word-of-mouth on the online popularity of restaurants: A comparison of consumer reviews and editor reviews. International Journal of Hospitality Management, 29(4), 694-700. doi:10.1016/j.ijhm.2010.02.002 
Figure 1. Conceptual framework

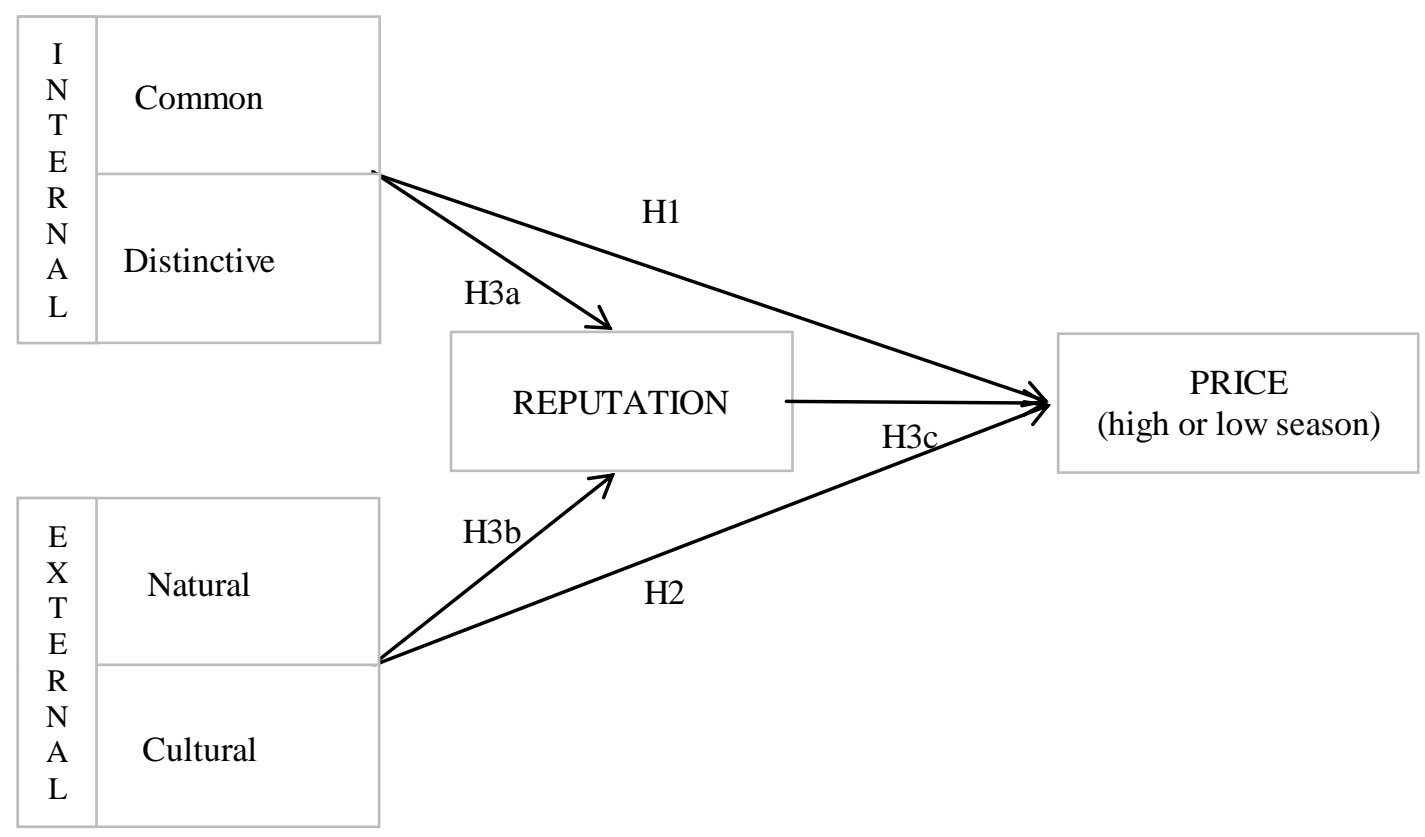


Table 1. Classification of variables

\begin{tabular}{|c|c|c|c|c|c|c|}
\hline Type & Variable & Variable description & Average $^{(\mathbf{1})}$ & St. Dev. & Min & Max \\
\hline \multirow[t]{2}{*}{ Price $(\mathrm{P})$} & $\mathrm{PH}$ & $\begin{array}{l}\text { Price, per night, per person } \\
\text { (high season) }\end{array}$ & 35.78 & 11.64 & 15 & 112.5 \\
\hline & PL & $\begin{array}{l}\text { Price, per night, per person } \\
\text { (low season) }\end{array}$ & 33.67 & 9.61 & 15 & 95 \\
\hline \multirow{11}{*}{$\begin{array}{l}\text { Internal, } \\
\text { Common } \\
\text { hotel services } \\
\text { and facilities } \\
\text { (IC) }\end{array}$} & REST & Restaurant & $46.0 \%$ & & & \\
\hline & POOL & Pool & $51.4 \%$ & & & \\
\hline & MEET & Meeting room & $14.0 \%$ & & & \\
\hline & DISAB & Services for disabled people & $20.8 \%$ & & & \\
\hline & PETS & Pets allowed & $51.0 \%$ & & & \\
\hline & KIDS & Game area for kids & $68.7 \%$ & & & \\
\hline & BIKES & Bike rental & $34.1 \%$ & & & \\
\hline & TV & TV & $82.3 \%$ & & & \\
\hline & WIFI & Wi-fi service & $70.1 \%$ & & & \\
\hline & AIR & Air conditioning & $18.3 \%$ & & & \\
\hline & PARK & Parking & $75.8 \%$ & & & \\
\hline \multirow{9}{*}{$\begin{array}{l}\text { Internal, } \\
\text { Distinctive } \\
\text { agritourism } \\
\text { accommodati } \\
\text { on services } \\
\text { and facilities } \\
\text { (ID) }\end{array}$} & MENU & $\begin{array}{l}\text { Menu with typical own } \\
\text { products }\end{array}$ & $43.0 \%$ & & & \\
\hline & SELL & $\begin{array}{l}\text { Direct selling of own } \\
\text { products }\end{array}$ & $37.3 \%$ & & & \\
\hline & TAST & $\begin{array}{l}\text { Tasting experiences / food } \\
\& \text { wine events }\end{array}$ & $17.5 \%$ & & & \\
\hline & TRIP & $\begin{array}{l}\text { Organization of trips/ } \\
\text { excursions }\end{array}$ & $31.2 \%$ & & & \\
\hline & EDU & Didactic farm & $19.9 \%$ & & & \\
\hline & CLASS & $\begin{array}{l}\text { Specific classes (cooking, } \\
\text { horse-riding, etc.) }\end{array}$ & $16.0 \%$ & & & \\
\hline & WORK & $\begin{array}{l}\text { Participation to farming } \\
\text { works }\end{array}$ & $17.8 \%$ & & & \\
\hline & RIDE & Horse riding center & $7.1 \%$ & & & \\
\hline & FARM & Farm animals & $34.8 \%$ & & & \\
\hline \multirow{5}{*}{$\begin{array}{l}\text { External, } \\
\text { Natural } \\
\text { geographical } \\
\text { environment } \\
\text { (EN) }\end{array}$} & MOUNT & Mountains & $41.5 \%$ & & & \\
\hline & HILL & Hills & $40.0 \%$ & & & \\
\hline & PLAIN & Plain & $18.5 \%$ & & & \\
\hline & LAKE & Close to a lake & $17.3 \%$ & & & \\
\hline & SEA & Close to the sea & $14.8 \%$ & & & \\
\hline \multirow{4}{*}{$\begin{array}{l}\text { External, } \\
\text { Cultural } \\
\text { regional } \\
\text { variables } \\
\text { (EC) }\end{array}$} & PDIKM & $\begin{array}{l}\text { Number of PDI (per } 1000 \\
\text { km squared) }\end{array}$ & 0.607 & 0.483 & 0.000 & 1.793 \\
\hline & HERIKM & $\begin{array}{l}\text { Number of Heritage sites } \\
\text { (per } 1000 \mathrm{~km} \text { squared) }\end{array}$ & 0.108 & 0.088 & 0.000 & 0.304 \\
\hline & IAGRI & $\begin{array}{l}\text { Number of agritourism } \\
\text { establishments (per km } \\
\text { squared) }\end{array}$ & 0.082 & 0.970 & 0.030 & 0.414 \\
\hline & ITUR & $\begin{array}{l}\text { Number of tourists per } \\
\text { inhabitant }\end{array}$ & 5.586 & 7.052 & 1.354 & 35.656 \\
\hline \multirow{3}{*}{$\begin{array}{l}\text { Reputation } \\
\text { (R) }\end{array}$} & RATE & $\begin{array}{l}\text { Agritourism third-party } \\
\text { rating ( } 1 \text { if missing) }\end{array}$ & 2.16 & 1.48 & 1 & 5 \\
\hline & NREV & Number of reviews & 16.26 & 40.15 & 0 & 481 \\
\hline & VREV & Value of reviews & 4.52 & 0.39 & 1.5 & 5 \\
\hline
\end{tabular}

In the case of dummy variables (taking value 1 if the service or characteristic is present and value 0 if it is not), the study reports the average value, which corresponds to the percentage of agritourism in the sample holding that specific characteristic. 
Table 2. Price determinants (Shapley Value Regression)

\begin{tabular}{llllll}
\hline & & \multicolumn{2}{c}{ HIGH SEASON } & \multicolumn{2}{c}{ LOW SEASON } \\
\hline Variable group & Variable & $\begin{array}{l}\text { Individual } \\
\text { contribution }\end{array}$ & $\begin{array}{l}\text { Group } \\
\text { contribution }\end{array}$ & $\begin{array}{l}\text { Individual } \\
\text { contribution }\end{array}$ & $\begin{array}{l}\text { Group } \\
\text { contribution }\end{array}$ \\
\hline $\begin{array}{l}\text { Internal } \\
\text { attributes }\end{array}$ & Common & $\begin{array}{l}42.3 \% \\
7.7 \%\end{array}$ & $50.0 \%$ & $54.0 \%$ & $62.1 \%$ \\
\hline \multirow{2}{*}{$\begin{array}{l}\text { External } \\
\text { attributes }\end{array}$} & Distinctive & Country dummies & $19.1 \%$ & $8.1 \%$ & $16.3 \%$ \\
& Natural environment & $8.7 \%$ & $50.0 \%$ & $4.9 \%$ & $37.9 \%$ \\
\hline R-squared & Cultural environment & $22.2 \%$ & & $16.7 \%$ & \\
\hline
\end{tabular}

Dependent variable is $\ln$ (Price). The R-squared of hedonic price regression of Model 1 is decomposed according to its determinants, by means of Shapley-Owen technique. Thus, each value represents the relative contribution to $R$-squared of each group of factors.

Table 3a. Sensitivity analysis by sub-samples (High Season)

\begin{tabular}{l|cc|ccccc}
\cline { 5 - 8 } & \multicolumn{2}{|c}{ Type of location } & \multicolumn{5}{c}{ Country } \\
\cline { 5 - 8 } & Mountain & Plain & Austria & France & Germany & Italy & Spain \\
\hline N. observations & 534 & 752 & 261 & 259 & 261 & 265 & 240 \\
\hline Common & $55.5 \%$ & $36.3 \%$ & $78.9 \%$ & $62.4 \%$ & $28.7 \%$ & $46.3 \%$ & $24.6 \%$ \\
Distinctive & $11.8 \%$ & $7.1 \%$ & $10.9 \%$ & $10.1 \%$ & $24.2 \%$ & $26.2 \%$ & $6.7 \%$ \\
\hline Country & $20.1 \%$ & $19.8 \%$ & & & & & \\
Natural & $1.0 \%$ & $6.3 \%$ & $1.3 \%$ & $2.0 \%$ & $10.2 \%$ & $6.2 \%$ & $15.7 \%$ \\
Cultural & $11.7 \%$ & $30.5 \%$ & $8.9 \%$ & $25.5 \%$ & $37.0 \%$ & $21.3 \%$ & $53.0 \%$ \\
\hline R-squared & 0.315 & 0.438 & 0.419 & 0.257 & 0.295 & 0.449 & 0.579 \\
\hline
\end{tabular}

The R-squared of hedonic price regression of Model 1 is decomposed according to its determinants, by means of Shapley-Owen technique. Thus, each value represents the relative contribution to $R$-squared of each group of factors.

Table 3b. Sensitivity analysis by sub-samples (Low Season)

\begin{tabular}{l|cc|ccccc}
\hline & \multicolumn{2}{|c|}{ Type of location } & \multicolumn{5}{c}{ Country } \\
& Mountain & Plain & Austria & France & Germany & Italy & Spain \\
\hline N. observations & 534 & 752 & 261 & 259 & 261 & 265 & 240 \\
\hline Common & $64.4 \%$ & $44.3 \%$ & $78.9 \%$ & $62.5 \%$ & $28.7 \%$ & $43.3 \%$ & $27.9 \%$ \\
Distinctive & $11.0 \%$ & $8.2 \%$ & $10.9 \%$ & $20.4 \%$ & $24.2 \%$ & $27.0 \%$ & $8.6 \%$ \\
\hline Country & $17.1 \%$ & $14.0 \%$ & & & & & \\
Natural & $1.1 \%$ & $3.9 \%$ & $1.3 \%$ & $1.6 \%$ & $10.2 \%$ & $6.0 \%$ & $8.7 \%$ \\
Cultural & $6.4 \%$ & $29.6 \%$ & $8.9 \%$ & $15.5 \%$ & $37.0 \%$ & $23.7 \%$ & $54.7 \%$ \\
\hline R-squared & 0.287 & 0.321 & 0.419 & 0.211 & 0.295 & 0.423 & 0.484 \\
\hline
\end{tabular}

The R-squared of hedonic price regression of Model 1 is decomposed according to its determinants, by means of Shapley-Owen technique. Thus, each value represents the relative contribution to $R$-squared of each group of factors. 
Table 4. Reputation determinants (Shapley Value Regression)

\begin{tabular}{llll}
\hline Variable group & Variable & $\begin{array}{l}\text { Individual } \\
\text { contribution }\end{array}$ & $\begin{array}{l}\text { Group } \\
\text { contribution }\end{array}$ \\
\hline $\begin{array}{l}\text { Internal } \\
\text { attributes }\end{array}$ & $\begin{array}{l}\text { Common hotel acc. services } \\
\text { Distinctive agritourism acc. } \\
\text { services }\end{array}$ & $27.8 \%$ & $39.6 \%$ \\
\hline \multirow{2}{*}{$\begin{array}{l}\text { External } \\
\text { attributes }\end{array}$} & Country dummies & $28.9 \%$ & \\
& Natural environment & $2.8 \%$ & $60.4 \%$ \\
\hline
\end{tabular}

Dependent variable is PCAREP. $R$-squared $=0,382$.

The R-squared of Model 2 is decomposed according to its determinants, by means of Shapley-Owen technique. Thus, each value represents the relative contribution to $R$-squared of each group of factors.

Table 5. Price determinants (Shapley Value Regression including reputation)

\begin{tabular}{|c|c|c|c|c|c|}
\hline & & \multicolumn{2}{|c|}{ HIGH SEASON } & \multicolumn{2}{|c|}{ LOW SEASON } \\
\hline Variable group & Variable & $\begin{array}{l}\text { Individual } \\
\text { contribution }\end{array}$ & $\begin{array}{l}\text { Group } \\
\text { contribution }\end{array}$ & $\begin{array}{l}\text { Individual } \\
\text { contribution }\end{array}$ & $\begin{array}{l}\text { Group } \\
\text { contribution }\end{array}$ \\
\hline \multirow{2}{*}{$\begin{array}{l}\text { Internal } \\
\text { attributes }\end{array}$} & Common & $33.4 \%$ & \multirow{2}{*}{$39.4 \%$} & $40.0 \%$ & \multirow{2}{*}{$46.0 \%$} \\
\hline & Distinctive & $6.0 \%$ & & $6.0 \%$ & \\
\hline \multirow{3}{*}{$\begin{array}{l}\text { External } \\
\text { attributes }\end{array}$} & Country dummies & $15.0 \%$ & \multirow{3}{*}{$40.3 \%$} & $12.6 \%$ & \multirow{3}{*}{$28.7 \%$} \\
\hline & Natural environment & $7.7 \%$ & & $4.0 \%$ & \\
\hline & Cultural environment & $17.6 \%$ & & $12.1 \%$ & \\
\hline Reputation & Reputation index (PCAREP) & \multicolumn{2}{|r|}{$20.4 \%$} & \multicolumn{2}{|r|}{$25.3 \%$} \\
\hline R-squared & & \multicolumn{2}{|c|}{0.422} & \multicolumn{2}{|c|}{0.325} \\
\hline
\end{tabular}

